\title{
Pengaruh Model Cooperative Learning Tipe Artikulasi Terhadap Hasil Belajar Siswa di Sekolah Dasar
}

\author{
Diren Agasi ${ }^{1)}$, Desyandri ${ }^{2)}$, Farida F $^{3)}$ \\ ${ }^{1)}$ Mahasiswa, Universitas Negeri Padang, Indonesia \\ ${ }^{2}$ Pembimbing 1, Universitas Negeri Padang, Indonesia \\ ${ }^{3}$ Pembimbing 2, Universitas Negeri Padang, Indonesia
}

Email: ${ }^{1)}$ direnagasi2895@ @mail.com, ${ }^{2)}$ desyandri@ fip.unp.ac.id,${ }^{3)}$ faridafachrudin6@ gmail.com

\begin{abstract}
Abstrak
Tujuan penelitian ini dilakukan untuk mengetahui pengaruh model cooperative learning tipe artikulasi terhadap hasil belajar Pendidikan Kewarganegaraan (PKn) peserta didik di kelas IV Sekolah Dasar (SD), pada materi contoh sederhana pengaruh globalisasi dilingkungan.Metode penelitian yang dipakai adalah quasi eksperimen.Penelitian ini dilaksanakan di SDN 02 Sialang dan SDN 05 Sialang.Dimana terdapat dua sampel penelitian, yaitu kelompok control dan kelompok eksperimen yang masing - masing kelompok terdiri dari 31 orang peserta didik.Kelompok eksperimen diajarkan menggunakan model cooperative learning tipe artikulasi sedangkan kelompok control menggunakan model konvensional. Berdasarkan analisis data menggunakan uji-t, menunjukkan hasil belajar PKn peserta didik yang diajarkan dengan menggunakan model cooperative learning diperoleh nilai $t_{\text {hitung }}$ sebesar 6,3655 dan $t_{\text {abel }}$ sebesar 2, sehingga $t_{\text {hitung }}>t_{\text {tabel. }}$. Dengan demikian dapat dinyatakan bahwa terdapat pengaruh yang signifikan dalam menggunakan model cooperative learning tipe artikulasi terhadap hasil belajar peserta didik.
\end{abstract}

Kata Kunci: Model Cooperative Learning tipe artikulasi, PKn, Hasil belajar

\section{The Effect of Cooperative Learning Model Type Articulation to Students Learning Outcome in Elementary School}

\begin{abstract}
The study aims to determine the effect of model cooperative learning outcomes of students for citizenship education on concept simple example of globalization effect in the circles. The method used is a quasipexperimental methods. This study was conducted in SDN 02 and 05 Sialang. In this research have two sample is the experimental and control group with 31 students. The experimental group used the cooperative learning tipe of articulation model and the control group used approach conventional group. Base on data analysis using t-test, indicates that the learning outcomes of students who are taught model cooperative learning obtained $t_{\text {count }} 6,3655$ dan $t_{\text {table }} 2$. With the result that $t_{\text {count }}>t_{\text {table }}$, it can be concluded that there is significant relationship between learning cooperative learning type of articulation model on students learning outcomes.
\end{abstract}

Keyword: Cooperative Learning type of Articulation, citizenship education, students learning outcomes. 


\section{PENDAHULUAN}

Pembelajaran PKn merupakan mata pelajaran yang menginginkan pembentukan sikap peserta didik yang mencerminkan bagaimana menjadi warga negara yang baik serta memiliki hubungan sosial yang baik dilingkungan keluarga, sekolah,mapun dilingkungan masyarakat, dan memiliki wawasan serta aktif dalam proses pembelajaran PKn tersebut. Hal ini dapat dilaksanakan oleh guru dengan cara menggunakan berbagai model dalam pembelajaran tersebut. Keberhasilan guru dalam memilih dan melakukan inovasi pada model pembelajaran akan membawa pengaruh besar terhadap hasil belajar peserta didik, itu dikarenakan model pembelajaran yang digunakan menentukan bagaimana proses pembelajaran akan terlaksana.

Permasalahan ini dapat menyebabkan munculnya kecenderungan perilaku dan karakter peserta didik yang tidak beradat/tidak beradab, seperti: kurangnya rasa menghargai dan menghormati orang lain, kurangnya sopansantun, lebih mementingkan diri sendiri (Desyandri, 2018). Di samping itu, guru terkesan masih menggunakan paradigma pembelajaran konvensional, terutama metode ceramah atau tanya jawab pada setiap pembelajaran (Desyandri, 2012).

Berdasarkan observasi yang dilakukan oleh peneliti di SDN kenagarian Sialang pada tanggal 1 - 22 Februari 2018, ditemukan bahwa pembelajaran PKn yang dilakukan oleh guru masih menggunakan model konvensional, salah satunya adalah metode ceramah yaitu, menyampaikan suatu materi pemebelajaran secara lisan kepada peserta didik (Aqib \& Murtadlo, 2016:38). Model pembelajaran yang dipakai guru dapat membuat anak menjadi jenuh dan bosan dalam pembelajaran. Hal ini juga akan menyebabkan materi yang disampaikan oleh guru menjadi kurang dipahami oleh peserta didik. Serta pada saat guru menyampaikan materi monoton pada penggunaan buku sehingga komunikasinya berupa satu arah dan akhirnya siswa cendrung pasif dalam pembelajaran (Kuwati, dkk, 2007:2)

Melihat apa yang terjadi dilapangan, maka guru perlu melakukan inovasi dalam penggunaan model dalam proses pembelajaran, agar dapat mendorong keaktifan peserta didik untuk belajar sehingga pembelajaran menjadi lebih bermakna. Salah satu model yang bervariasi dalam pembelajaran adalah model Cooperative LearningTipe Artikulasi. Karena model ini akan menuntut peserta didik untuk bekerjasama dalam kelompok yang mempunyai peran sebagai penerima dan penyampai pesan sehingga peserta didik senang dalam proses pembelajaran (Huda, 2014:268)

\section{Model Cooperative Learning Tipe} Artikulasi berdasarkan Kurniawati (2010:4) menyebutkan bahwa model pembelajaran seperti permainan dalam kelompok yang memiliki sintaks membagi peserta didik menjadi penerima dan penyampai pesan yang diperoleh dari guru, dimana pesan itu berupa 
kartu pesan yang dibacakan oleh peserta didik yang berperan sebagai penyampai pesan ke peserta didik yang berperan sebagai penerima pesan begitu juga sebaliknya, sehingga pada akhirnya peserta didik tersebut membuat catatan - catatan kecil tentang pengetahuan baru yang diperolehnya didepan kelas. Serta Model Cooperative Learning Tipe Artikulasi dapat diterapkan dalam pembelajaran PKn pada materi contoh sederhana pengaruh globalisasi di lingkungan, dengan karakteristik materi yang tidak terlalu luas dan merupakan bacaan - bacaan berupa hafalan. Sehingga nanti terlihat apakah ada pengaruh yang signifikan dalam penggunaan model cooperative learning tipe artikulasi terhadap hasil belajar PKn peserta didik, yang pada akhirnya mendapatkan tujuan yaitu membuktikan adanya pengaruh yang signifikan dalam penggunaan model cooperative learning tipe artikulasi terhadap hasil belajar PKn peserta didik.

\section{METODE PENELITIAN}

Metode yang digunakan pada penelitian ini adalah quasi experiment dalam bentuk two group posttest-only yang merupakan bagian dari metode kuantitatif. Two group posttestonly merupakan desain penelitian yang penentuan kelompok eksperimen dankontrolnya dipilih secara acak (Prasetyo \& Jannah,2011:162).

Metode ini dapat dinyatakan sebagai metode penelitian yang digunakan untuk mencari pengaruh dari perlakuan yang dilakukan kepada sampel penelitian dalam kondisi yang terkendalikan.Dimana hasil belajar peserta didik merupakan data dari penelitian yang diperoleh dari dua kelompok sampel yaitu, kelompok eksperimen dan kelompok kontrol. Kelompok eksperimen diberi perlakuan dengan menggunakan model Cooperative Learning Tipe Artikulasi sedangkan kelompok kontrol hanya menggunakan model konvensional yang biasa dilakukan oleh guru pada mata pelajaran PKn.

$$
\text { Populasi adalah semua anggota }
$$

kelompok orang, kejadian atau objek - objek yang ditentukan dalam suatu penelitian yang mencakup wilayah yang luas(Rukeishi\&Cahyana,2015:39).Populasi pada penelitian ini adalah seluruh peserta didik kelas IV di Kenagarian Sialang mulai dari SDN 01-06 Sialang, yang berjumlah 164 orang.

Tabel 1. Populasi Penelitian

\begin{tabular}{cccc}
\hline Nama Sekolah & $\begin{array}{c}\text { Jumlah } \\
\text { Siswa }\end{array}$ & $\begin{array}{c}\text { Rerata } \\
\text { Kelas }\end{array}$ & Kurikulum \\
\hline SDN 01 Sialang & 22 & 79,95454 & K13 \\
SDN 02 Sialang & 31 & 73,70968 & KTSP \\
SDN 03 Sialang & 08 & 73,125 & KTSP \\
SDN 04 Sialang & 28 & 73,85714 & K13 \\
SDN 05 Sialang & 31 & 68,83871 & KTSP \\
SDN 06 Sialang & 44 & 75,6590 & K13 \\
$\quad$ Jumlah & 164 & & \\
\hline
\end{tabular}

Pengambilan sampel dilakukan dengan cara purposive sampling dan simple random sampling.purposive sampling adalah teknik pengambilan sampel dengan pertimbangan dan kriteria - kriteria tertentu dalam penentuannya (Sugiyono, 2012:83). Dimana dengan kriteria (1) sekolah menerapkan kurikulum KTSP,(2) jumlah peserta didik 
dikelas itu sama ataupun hampir sama,(3) kelas yang dijadika sampel setelah dilakukan uji normalitas dan homogenitas harus berdistribusi normal dan homogen(4) terdapat materi yang sama pada sekolah tersebut. Sehingga didapatkan kelompok eksperimen adalah kelas IV SDN 05 Sialang dan kelompok kontrol adalah kelas IV SDN 02 Sialangmelalui sistem undi, yang mekanisme pengundiannya adalah peneliti membuat duat buah undian pada kertas yang berisikan tulisan kelas eksperimen dan kelas kontrol yang akan diambil oleh masing masing ketua kelas.

Dimana masing - masing kelompok memiliki jumlah peserta didik sebanyak 31 orang. Dilihat dari uji normalitas kelas eksperimen dan kelas kontrol diperoleh data sebagai berikut; kelas eksperimen sebesar Lhitung 0,119489 dan kelas kontrol $\mathrm{L}_{\text {hitung }}$ 0,138348 dengan $\mathrm{L}_{\text {tabel }}$ sebesar 0,159 kedua kelas berdistribusi normal.

Tabel 2. Sampel Penelitian

\begin{tabular}{|c|c|c|c|}
\hline $\begin{array}{c}\text { Nama } \\
\text { Sekolah }\end{array}$ & $\begin{array}{l}\text { Jumlah } \\
\text { Siswa }\end{array}$ & $\begin{array}{c}\text { Uji } \\
\text { Normalitas }\end{array}$ & $\begin{array}{c}\text { Uji } \\
\text { Homogenitas }\end{array}$ \\
\hline $\begin{array}{c}\text { SDN 05 } \\
\text { Sialang } \\
\text { (eksperimen) }\end{array}$ & 31 & $\begin{array}{l}0,119489< \\
0,159 \\
\text { (normal) }\end{array}$ & $\begin{array}{l}1,608<1,84 \\
\text { (homogen) }\end{array}$ \\
\hline $\begin{array}{c}\text { SDN 02 } \\
\text { Sialang } \\
\text { (kontrol) }\end{array}$ & 31 & $\begin{array}{l}0,138348< \\
0,159 \\
\text { (normal) }\end{array}$ & $\begin{array}{r}1,608<1,84 \\
\quad \text { (homogen }\end{array}$ \\
\hline
\end{tabular}

Data yang dianalisis dalam penelitian ini adalah hasil belajar PKn ranah kognitif yang dikumpulkan melalui tes objektif yang diberikan.Tes tersebut sebelumnya telah diujicobakan di SDN 01 Muaro Paiti.Teknik yang digunakan untuk menganalisis data guna menguji hipotesis penelitian adalah uji-t.Untuk bisa melakukan pengujian hipotesis, ada beberapa syarat yang harus dipenuhi dan dibuktikan. Syarat tersebut adalah: (1) data yang dianalisis harus berdistribusi normal,(2) kedua data yang akan dianalisis harus bersifat homogen. Untuk itu dilakukanlah uji prasarat analisis dengan melakukan uji normalitas dan homogenitas.

\section{HASIL PENELITIAN}

\section{A. Hasil Data Tes}

Datayang dideskripsikan disini adalah data hasil posttestdari kedua kelas.Data yang digunakan dalam penelitian ini berupa data kuantitatif berupa tes objektif dalam bentuk posttest.

Tabel 3. Data Statistik Hasil Penelitian Posttest

\begin{tabular}{lcc}
\hline \multicolumn{1}{c}{ Data } & $\begin{array}{c}\text { Kelompok } \\
\text { eksperimen }\end{array}$ & $\begin{array}{c}\text { Kelompok } \\
\text { kontrol }\end{array}$ \\
\hline Nilai Terendah & 70 & 53 \\
Nilai Tertinggi & 97 & 87 \\
Rata-rata & 86,58065 & 65,96774 \\
SD & 7,680691 & 10,16789 \\
\hline
\end{tabular}

Berdasarkan data diatas dapatdinyatakan bahwa rata - rata kelas eksperimen sudah diatas KKM (75), dengan rincian nilai terbesar diperoleh oleh lima orang peserta didik dan satu orang peserta didik mendapatkan nilai terendah serta dua orang peserta didik memiliki nilai dibawah KKM.

Sedangkan untuk kelas kontrol ratarata yang diperoleh ternyata berada dibawah KKM (75), dengan rincian dua orang peserta didik yang mendapat nilai tertinggi dan tiga orang peserta didik yang memperoleh nilai terendah serta 22 orang peserta didik memiliki nilai dibawah KKM. 


\section{B. Hasil Analisis Data Tes}

1. Uji normalitas posttest kelas eksperimen dan kontrol

\begin{tabular}{lcclc}
\hline Kelas & $\mathbf{N}$ & $\mathbf{a}$ & Lhitung & Ltabel \\
\hline Eksperimen & 31 & 0,05 & 0,026537753 & 0,159 \\
Kontrol & 31 & 0,05 & 0,022332 & 0,159
\end{tabular}

Dari tabel diatas dapat dilihat bahwa kedua kelompok, baik itu kelompok eksperimen maupun kelompok kontrol sama - sama berdistribusi normal karena $\mathrm{L}_{\text {hitung }}<\mathrm{L}_{\text {tabel }}$ (Sudjana,2005:466)

2. Uji homogenitas posttest kelas eksperimen dan kontrol

\begin{tabular}{llll}
\hline Kelas & varian & $\mathbf{f}_{\text {hitung }}$ & $\mathbf{f}_{\text {tabel }}$ \\
\hline Eksperimen & 59,14672 & 1,74796 & 1,84 \\
Kontrol & 103,3861 & & \\
\hline
\end{tabular}

Dari tabel diatas dapat dilihat bahwa kedua kelompok berdasarkan hasil posttest berasal dari populasi yang homogen karena memenuhi kriteria $\mathrm{f}_{\text {hitung }}<\mathrm{f}_{\text {tabel }}$ (Irianto, 2008:276).

Sedangkan dari pengujian hipotesis diketahui bahwa hasil perhitungan uji-t dengan rumus polled varians diperoleh $\mathrm{t}_{\text {hitung }}$ sebesar 6,3655 dan $\mathrm{t}_{\text {tabel }}$ pada taraf signifikansi 5\%adalah 2. Sehingga, $\mathrm{t}_{\text {hitung }}>$ $t_{\text {tabelyaitu }} \quad 6,3655>2$.sehingga $\quad H_{o} \quad$ ditolak (Sugiyono,2012:273). Sehingga dapat disimpulkan bahwa penggunaan model cooperative learning tipe artikulasi memberikan pengaruh yang signifikan terhadap hasil belajar PKn dengan materi contoh sederhana pengaruh globalisasi dilingkungan.

\section{PEMBAHASAN}

Hasil data pada saat posttest, yakni rata-rata kelas eksperimen yaitu 86,58065, dengan perolehan nilai posttest terbesar 97 dan nilai terkecil 70 . Sedangkan rata-rata kelas kontrol adalah 65,96774, dengan perolehan nilai terbesar 87 dan nilai terkecil 53. Hasil perhitungan menggunakan uji $t$, diperoleh $t_{\text {hitungsebesar }}$ 6,3655 dan pada taraf signifikan $\alpha=0,05$ didapat $t_{\text {tabel }}$ sebesar 2. Hasil yang didapat adalah $\mathrm{t}_{\text {hitung }}(6,3655)>\mathrm{t}_{\text {tabel }}(2)$, maka Ho ditolak (Sugiyono,2012:273). Artinya penguasaan konsep kelas eksperimen berbeda dengan penguasaan konsep kelas kontrol.

Berdasarkan uji hipotesis dan keterlaksanaan model cooperative learning tipe artikulasi, menunjukkan bahwa terdapat pengaruh yang signifikan antara hasil belajar PKn peserta didik yang diajarkan menggunakan model cooperative learning tipe artikulasi dengan hasil belajar siswa yang diajarkan secara konvensional.Sebagaimana ditunjukkan oleh nilai rata-rata posttest kelas eksperimen lebih besar dibanding nilai ratarata posttest kelas kontrol.Sehingga dapat disimpulkan bahwa model cooperative learning tipe artikulasi berpengaruh secara signifikan terhadap hasil belajar PKn peserta didik.

Berikut adalah diagram rerata kelas eksperimen dan kelas kontrol 


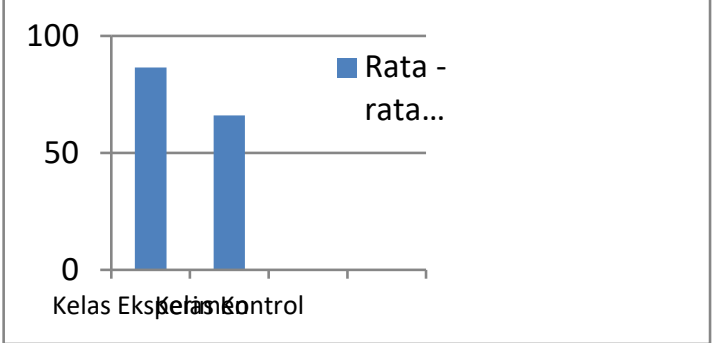

Selama pembelajaran di kelas eksperimen, peserta didik mengerjakan LDK secara berkelompok sebagai cara bagi peserta didik menemukan pengetahuan mereka sendiri, berdasarkan gambar yang mereka amati pada LDK. Setelah selesai mengerjakan LDK, masing-masing perwakilan kelompok mengemukakan hasil diskusinya.Hal ini dimaksudkan untuk mengungkapkan jawaban LDK yang telah dikerjakan secara berkelompok.

Selain menegrjakan LDK peserta didik juga diberikan kartu pesan kepada peserta didik yang berperan sebagai penyampai pesan kepada peserta didik yang berperan sebagai penerima pesan. Sebagai contoh, Pengaruh sederhana globalisasi di bidang komunikasi yaitu telpon membantu kehidupan manusia untuk selalu terhubung dengan orang lain yang berjauhan tempat, informasi ini kemudian dicatat oleh penerima pesan dan pada akhir kegiatan salah satu peserta didik akan menyampaikan hasil diskusi mereka didepan kelas serta ditanggapi oleh peserta didik lainnya.

Pada penialain ranah afektif, peserta didik diberi lembar penilaian diri (Friska,2015:6) yang berisi tentang filterisasi sikap peserta didik terhadap pengaruh baik ataupun buruk dari globalisasi dilingkungannya.

Penialain ranah kognitifnya peneliti memberi tugas kepada peserta didik untuk membuat sebuah klippin mengenai contoh sederhana pengaruh globalisasi dilingkunganya, yang mana nanti peneliti dapat melihat kepada aspek kesiapan peserta didik, proses, maupun hasil kerja yang dilakukannya (Friska,2015:8)

Hasil penelitian ini menunjukkan bahwa model cooperative learning tipe artikulasi memberikan dampak positif terhadap hasil belajar peserta didik.Hal ini dapat dilihat dari banyaknya peserta didik yang mencapai nilai diatas KKM. Serta dengan menggunakan model cooperative learning tipe artikulasi peserta didik bisa menjadi lebih paham dengan materi, aktif dalam proses pembelajaran, bekerjasama dalam kelompok, dan meningkatkan keterampilan bertanya dan menjawab pertanyaan. Sehingga terbentuklah kecerdasan peserta didik yang mencakup ketiga ranah tersebut dimulai dari ranah kognitif, afektif, dan Psikomotor (Sukma,2016:4)

Pembelajaran PKn menggunakan model cooperative learning tipe artikulasi dilaksanakan dengan membentuk peserta didik menjadi kelompok berpasangan, setelah itu guru membagikan tugas dari peserta didik mana yang menjadi penerima pesan dan mana yang menjadi penyampai pesan, begitu juga sebaliknya. Setelah peserta didik melakukan wawancara dengan teman kelompoknya maka 
mereka menyampaikan apa yang mereka ketahui tentang materi yang baru mereka terima tersebut. Setelah itu peserta didik lain mengomentari apa yang di sampaikan oleh kelompok lain sehingga interaksi dan kerjasama dalam proses pembelajaran berjalan dengan baik. Setelah itu guru akan menanyakan kembali mana materi yang kurang dipahami oleh peserta didik, sehingga guru memberikan penguatan dan pengulangan kepada materi tersebut sehingga dimungkinkan tidak ada peserta didik yang tidak paham akan materi yang dibelajarkan tadi. Setelah itu guru dan peserta didik bersama - sama menyimpulkan pembelajaran pada hari itu sehingga pembelajaran akan lebih bermakna.

\section{KESIMPULAN DAN SARAN}

Berdasarkan hasil analisis data dapat disimpulkan bahwa model cooperative learning tipe artikulasiberpengaruh secara signifikan terhadap hasil belajar PKn peserta didik pada materi contoh pengaruh globalisasi di lingkungan. Hal ini ditunjukkan dari perolehan hasil perhitungan uji hipotesis posttest melalui uji t pada taraf signifikan 0,05, dimana $t_{\text {hitung }}>\mathrm{t}_{\text {tabel }}$ yaitu $\mathrm{t}_{\text {hitung }}(6,3655)>\mathrm{t}_{\text {tabel }}$ (2), sehingga dapat dinyatakan bahwa model cooperative learning tipe artikulasi merupakan solusi yang tepat untuk mengembangkan pembelajaran yang memberikan pengaruh baik terhadap hasil belajar peserta didik.

Berdasarkan kesimpulan di atas, selanjutnya dapat diajukan saran yang dapat dijadikan pertimbangan, yaitu :model cooperative learning tipe artikulasi dapat digunakan pada konsep yang karakteristiknya sama dengan contoh sederhana pengaruh globalisasi.

\section{DAFTAR RUJUKAN}

Agib, Z \& Murtado, A. (2016). Kumpulan Metode Pembelajaran kreatif dan inovatif. Bandung: Sarana Tutorial Nurami Sejahtera

Desyandri. (2012). The Usage of Contextual Teaching and Learning (CTL) Approach to improve the process and learning outcome of Singing to the Student Class III Elementary School YPKK of Padang State University. Pedagogi: Jurnal Ilmu Pendidikan, 12(1), 36-52. Retrieved from http://pedagogi.ppj.unp.ac.id/index.php /pedagogi/article/view/231

Desyandri. (2018). Nilai-nilai Kearifan Lokal untuk Menumbuhkembangkan Literasi Budaya di Sekolah Dasar. Sekolah Dasar: Kajian Teori Dan Praktik Pendidikan, 27(1), 1-9. https://doi.org/http://dx.doi.org/10.179 77/um009v27i12018p001

Friska, O. (2015). Analisis Kemampuan Siswa Kelas X Pada Ranah Kognitif, Afektif, dan Psikomotor. Jurnal Fisika dan Pendidikan Fisika. Vol 1. Nomor 2

Huda, M. (2017). Model - model Pengajaran dan Pembelajaran. Yogyakarta: Pustaka Belajar

Irianto, A. (2008). Statistik Konsep Dasar, Aplikasi, dan Pengembangannya. Jakarta: Prenamedia Group

Kurniawati, S., Eka, dkk. (2010). Penerapan Model Pembelajaran untuk Meningkatkan Proses dan Hasil Belajar Siswa Pada Mata Pelajaran IPS Materi Hidrosfer Kelas VII H SMP Negeri 3 kartasura. Jurnal Model Pembelajaran Artikulasi (JP UNS) vol.1 no. 1.Hlm:5-6

Kuwati, dkk. (2007). Model Pembelajaran TGT dalam Meningkatkan Pembelajaran PKn Siswa Kelas IV Sekolah Dasar. Jurnal Model dan 
Pendidikan, Volume

Nomorl.Halaman:1

Prasetyo, B \& Jannah, Lina, M. (2011).

Metode Penelitian Kuantitatif. Jakarta:

Rajawali Press

Rukeishi \& Cahyana. (2015). Metododologi

Penelitian Pendidikan. Jakarta: PT.

Grafindo Persada

Sugiyono. 2012. Metode Penelitian

Pendidikan Pendekatan Kuantitatif,

Kualitatif, RnD. Bandung: Alfabeta

Sukma, E. (2016). Kompetensi Kognitif

Pembelajaran Apresiasi Sastra di

Sekolah Dasar. Jurnal Pendidikan

Bahasa dan Sastra Indonesia. Vol 2.

HIm 1 - 11 